\title{
Response of Ultimobranchial and Parathyroid Glands of the Indian Skipper Frog, Euphlyctis cyanophlyctis to Cadmium Toxicity
}

\section{Ajai Kumar Srivastav*1(D), Shilpi Srivastava1(D), Sunil Kumar Srivastav1(D), Caterina Faggio ${ }^{(D)}$, Toshio Sekiguchi ${ }^{3}(D)$, Nobuo Suzuki ${ }^{3}(D)$}

1. Department of Zoology, DDU Gorakhpur University, Gorakhpur, India.

2. Department of Chemical, Biological, Pharmaceutical and Environmental Sciences, University of Messina. messina, Italy.

3. PhD of Zoology and Environmental Sciences, Institute of Nature and Environmental Technology, Kanazawa University, Ogi, Noto-cho, Ishikawa, Japan.

\begin{tabular}{l}
\hline Article Info \\
\hline Article Type: \\
Original Research \\
\hline Article History: \\
Received: 2019-01-03 \\
Accepted: 2019-02-04 \\
\hline * Corresponding Author: \\
Ajai Kumar Srivastav \\
Department of Zoology, DDU \\
Gorakhpur University, Gorakhpur, \\
India. \\
E-mail:ajaiksrivastav@hotmail.com
\end{tabular}

A B S T R A C T

Background:

Cadmium toxicity has been shown in aquatic animals but the effect on frog's endocrine glands is not known. We investigated the effects of cadmium on ultimobranchial and parathyroid glands of Indian skipper frog, Euphlyctis cyanophlyctis.

\section{Methods:}

Frogs were exposed to cadmium chloride for short and long terms and sacrificed after 24, 48, 72 or $96 \mathrm{~h}$ (short-term) and after 5, 10, 15 and 30 days (long-term).

Results:

After 48h of cadmium exposure, serum calcium levels decreased and persisted for 96h. After 96h of exposure, weak staining of the ultimobranchial cells was noted, and the nuclear volumes decreased. The histological structures of parathyroid cells remained unchanged.

Frogs exposed to cadmium exhibited decreased serum calcium levels from day 10 to day 30. After 15 days of cadmium exposure, ultimobranchial cells exhibited a decline in staining response and the nuclear volume also decreased. The follicular epithelia of the ultimobranchial glands appeared to be reduced at certain areas. After 30 days of cadmium exposure, the nuclear volume was further decreased and the follicular epithelia shrunk and appeared as a single layer. Cellular degeneration and vacuolization were also noticed in the gland. After day 15 of cadmium exposure, the nuclear volume of the parathyroid cells increased with elongated and hyperchromatic appearance. These changes were exaggerated on day 30 of cadmium exposure and few cell lyses appeared among parathyroid cells.

\section{Conclusions:}

Cadmium adversely affected the calcium regulating glands, ultimobranchial and parathyroid glands of the Indian frogs, Euphlyctis cyanophlyctis.

Keywords:

Cadmium Toxicity, Euphlyctis cyanophlyctis, Indian Skipper Frog, Parathyroid Glands Cells, Ultimobranchial Glands.

How to cite this paper

Srivastav AK, Srivastava S, Srivastav SK, Faggio C, Sekiguchi T, Suzuki N. Response of Ultimobranchial and Parathyroid Glands of the Indian Skipper Frog, Euphlyctis cyanophlyctis to Cadmium Toxicity. Iran J Toxicol. 2019; 13 (3): 39-44

\section{INTRODUCTION}

Several species of frogs have experienced notable population declines $(\underline{1-6})$. Many factors have been suggested to cause the decline in global amphibian population decline, such as climate change, UV-B radiation, diseases and exposure to contaminants during frog's life $(\underline{4,5,6})$.

Heavy metals are toxic elements which can be accumulated in organisms and may cause physiological disturbances ( $\underline{7-10})$. Cadmium is a heavy metal which never occurs in nature in its elemental form but exists as compound with other elements $(\underline{10})$. Cadmium is the most toxic metal $(\underline{11,12})$ and is poorly regulated by organisms and therefore whole-body residues will increase with ongoing cadmium exposures $(\underline{13})$. When cadmium is introduced in freshwater, it may adversely affect the aquatic organisms.

There exists a report regarding the effects of cadmium on the blood electrolytes of frog ( $\underline{5})$ but the effects on calcium regulating endocrine glands, i.e., 
ultimobranchial and parathyroid glands have not been studied so far. Hence, the aim of this study was to investigate the effects of cadmium exposure on the ultimobranchial and parathyroid glands of Indian skipper frog, E. cyanophlyctis (E. cyanophlyctis).

\section{MATERIALS AND METHODS}

Ninety six frogs (48 for short- \& long-term, each experiment), E. cyanophlyctis (both sexes; body wt. 12$173 \mathrm{~g}$ ) were selected and acclimatized for 15 days in 30L of all glass aquaria. Small-mesh dip-net of soft material was used for gentle handling of frogs during the study, and care was taken to minimize stress to the frogs. Dead frogs were discarded immediately. Frogs were not fed $24 \mathrm{~h}$ before and during the experiment. Short-term and long-term experiments were performed. Animal handling and sacrifice were carried out following the guidelines provided by Ethics Committee of Gorakhpur University, India.

Short-term Exposure: The frogs $(\mathrm{N}=24)$ were subjected to $18.432 \mathrm{mg} / \mathrm{L}$ of cadmium chloride (0.8 of $96 \mathrm{~h} \mathrm{LC}_{50}$ value). Frogs were kept in groups of 10 in $30 \mathrm{~L}$ media. Six frogs were sacrificed on each interval from the control and experimental groups (cadmium chloride exposed) after 24, 48, 72 and 96h. Blood was collected and the ultimobranchial and parathyroid glands were fixed for histology processing.

Long-term Exposure: The frogs $(\mathrm{N}=24)$ were acclimatized for 15 days to the laboratory conditions and subjected to $4.608 \mathrm{mg} / \mathrm{L}\left(0.2\right.$ of $96 \mathrm{~h} \mathrm{LC}_{50}$ value) of cadmium chloride for 30 days. Simultaneously, a control group $(\mathrm{N}=24)$ was also used for comparison. Six frogs from each of the control and experimental groups (cadmium chloride exposed) were sacrificed after 5, 10, 15 and 30 days. The blood was collected and the ultimobranchial and parathyroid glands were fixed for histology processing.

In each experiment, frogs were slightly anesthetized with ether and blood samples were collected by cardiac puncture. The samples were allowed to clot at room temperature. Sera were separated by centrifugation (at $3000 \mathrm{rpm}$ ) and kept at $-20^{\circ} \mathrm{C}$ until analyzed for serum calcium levels, using a commercially available diagnostic kit (calcium kit, Sigma-Aldrich; Germany). All determinations were carried out in duplicates for each sample, from the short- and long-term experiments.

After blood sample collections, glottis together with a small piece of the surrounding tissue were extirpated and fixed in aqueous Bouin's solution. The fixed tissues were dehydrated in an ethanol gradient, treated with a clearing agent, infiltrated and embedded in paraffin, sectioned at $6 \mu \mathrm{m}$, floated on a heated water bath and mounted on glass slides. After drying overnight, paraffin was removed with a clearing agent; tissue was rehydrated in an ethanol gradient and stained with hematoxylin and eosin (H\&E) for light microscopic examination. Photomicrographs were taken, using an Olympus CH 20i microscope and Olympus E 420 camera.
The nuclear indices of the cells from ultimobranchial and parathyroid glands were taken, using an ocular micrometer and then the nuclear volume was calculated as: volume $=4 / 3 \pi a b^{2}$, where ' $a$ ' is the major semiaxis and ' $b$ ' is the minor semiaxis. In the glands, when there are degenerating nuclei, only the indices of intact nuclei were measured. Nuclear index is defined as the maximal length and width for each nucleus observed microscopically.

All data were presented as the means \pm S.E. of six specimens and Student's $t$-test was used to determine the statistical significance. In all studies, the experimental group was compared with the corresponding control group over an identical experimentation time period.

\section{RESULTS}

Short-term Cadmium Chloride Exposure: The serum calcium levels of the frogs exposed to cadmium for $24 \mathrm{~h}\left(80 \%\right.$ of $\left.96 \mathrm{~h}, \mathrm{LC}_{50}\right)$ exhibited no histological alterations. After $48 \mathrm{~h}$ cadmium exposure; however, the calcium levels declined. This response persisted until the end of the experiment ( 96 h; Fig. 1).

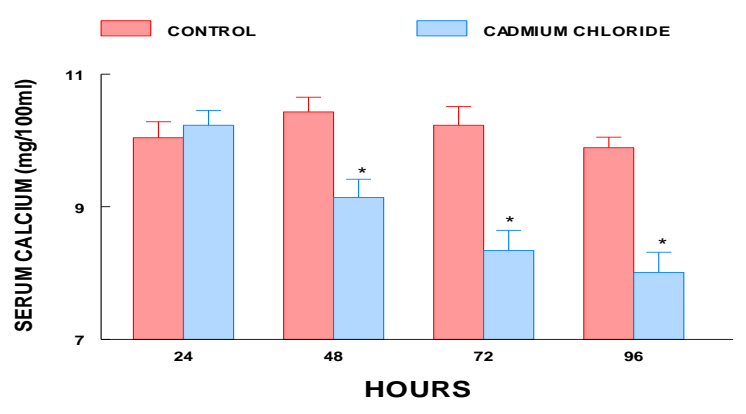

Figure 1. Serum calcium levels of short-term cadmium chloride treated Euphlyctis cyanophlyctis. Values are mean \pm S.E. of six specimens. Asterisk indicates significant differences $(\mathrm{P}<0.05)$ from control.

The ultimobranchial glands of the control frogs were paired with follicular tissue situated laterally to the glottis, beneath the pharyngeal epithelia. The epithelia of the follicles are pseudo-stratified, encircling a large lumen filled with colloid-like, eosinophilic material (Fig. 2). Based upon the position and shape of the nuclei, three different cell types were identified in the follicular epithelia of the ultimobranchial glands as follows (Fig. 3):

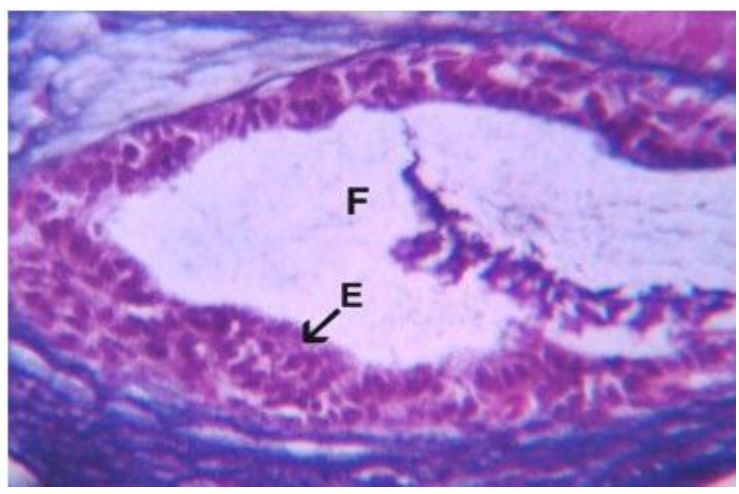

Figure 2. Ultimobranchial gland of control E. cyanophlyctis exhibiting follicle (F) and epithelia. H\&E stain; mag. x 200. 


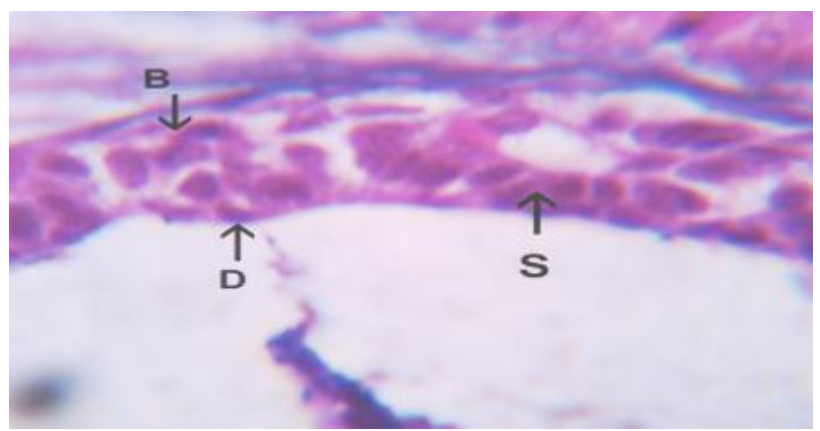

Figure 3. Follicular epithelium of ultimobranchial gland of normal $E$ cyanophlyctis exhibiting basal (B), secretory (S) and degenerating (D) cells. H\&E stain; mag x 500.

i. Basal Cells: These cells were situated towards the basal region of the follicle and were touching the basement membrane. They did not extend up to the surface. These cells had round or oval nuclei.

ii. Secretory or Storage Cells: They were predominantly elongated cells with homogeneously stained nuclei and fine reticular chromatin patterns. These cells extended from the basement membrane of the follicle to the surface of the lumen.

iii. Degenerate Cells: These cells contained irregularly dark stained nuclei and exhibited clumping of the chromatin material. Usually, they were in contact with the free surface and had very little cytoplasm. Up to $72 \mathrm{~h}$ of exposure to cadmium the ultimobranchial glands exhibited no histological changes. After 96h; however, a weak staining response was noted in the cytoplasm of ultimobranchial gland cells (Fig. 4). The nuclear volume of these cells was slightly shrunk (Fig. 5).

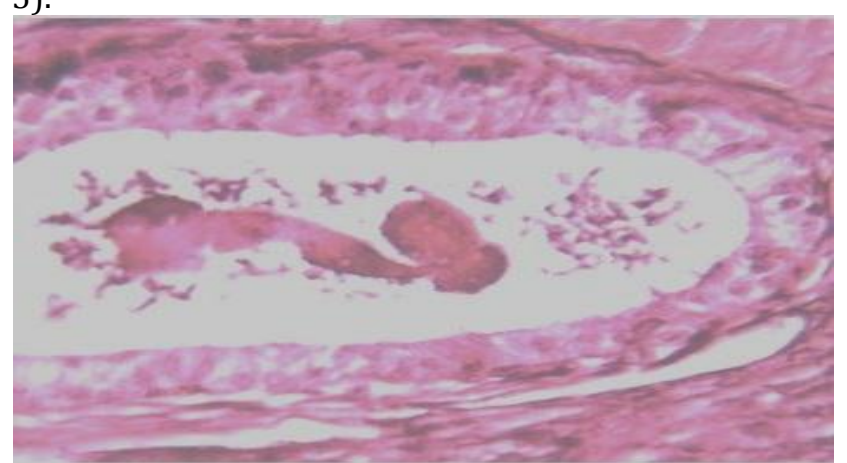

Figure 4. Ultimobranchial gland of $96 \mathrm{~h}$ cadmium chloride treated Euphlyctis cyanophlyctis exhibiting weak staining response of the cytoplasm. H\&E stain; mag. x 200.

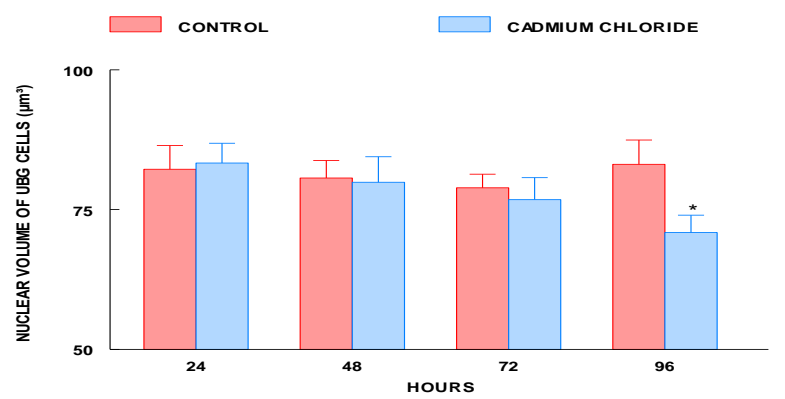

Figure 5. Nuclear volume of ultimobranchial cells of short-term cadmium chloride treated Euphlyctis cyanophlyctis. Values are mean \pm $\mathrm{SE}$ of six specimens. Asterisk indicates significant differences $(\mathrm{P}<0.05)$ from the control group.
In the control frogs, two parathyroid glands were situated on each side of the pre-cardiac region near the ventral branchial body and carotid artery. The glands were round or ovoid in shape and contained closely packed epithelial cells, surrounded by a connective tissue capsule, richly supplied with blood capillaries (Fig. 6). Connective tissue and blood capillaries were not seen inside the gland. The epithelial cells of parathyroid gland were arranged in whorls, and there was a single type of cells, with indistinct cell boundary, scanty cytoplasm and large nuclei and dense chromatin granules (Fig. 6). No changes in the histological structures and the nuclear volumes of parathyroid cells of cadmium exposed frogs were noted throughout the experiment (Fig. 7).

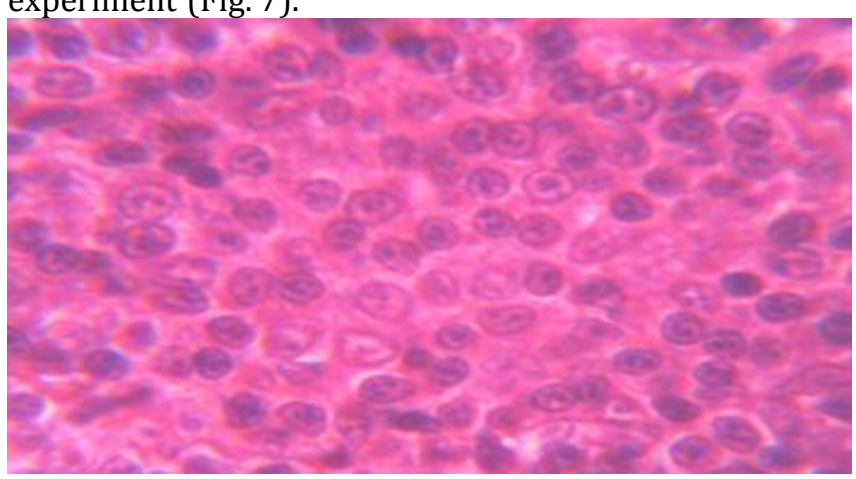

Figure 6. Parathyroid gland (PTG) of normal Euphlyctis cyanophlyctis showing single cell type. H\&E stain; mag x 500 .

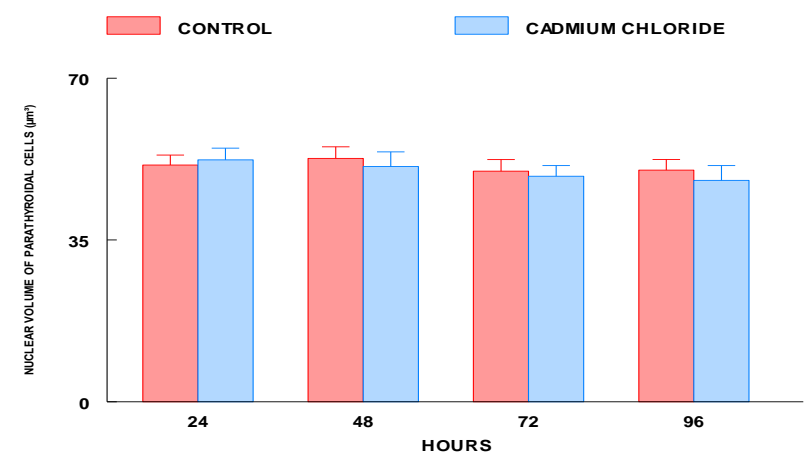

Figure 7. Nuclear volume of parathyroid cells of short-term cadmium chloride treated Euphlyctis cyanophlyctis. Values are mean \pm SE of six specimens.

Long-term Cadmium Chloride Exposure: The frogs exposed to cadmium for 5 days exhibited no change in the serum calcium levels. Thereafter, the levels decreased progressively from day 10 to day 30 , the end of the experiment (Fig. 8). No changes in the ultimobranchial glands of the control frogs were noted throughout the experiment.

Following 10 days of cadmium exposure, there was no change in the histological structures of the ultimobranchial glands. After 15 days; however, the gland cells exhibited a slight decrease in their staining response in the cytoplasm (Fig. 9) and the nuclear volumes decreased (Fig. 10). Moreover, the follicular epithelia appeared shrunk at certain places, resulting in relative enlargement of the follicular lumen (Fig. 11). 
After 30 days of cadmium exposure, the nuclear volume was further decreased (Fig. 9) and the epithelia appeared reduced in height and formed a single cell layer (Fig. 11). Cellular degeneration and vacuolization were also noted in the glands (Fig. 12).

There was no change in the parathyroid cells of the control frogs throughout the experiment. In cadmium treated frogs, the parathyroid cells remained unchanged up to 10 days. After 15 days of cadmium exposure; however, the nuclei of these cells exhibited an increase in volume (Fig. 13) and they were elongated and hyperchromatic (Fig. 14). These changes were exaggerated on day 30. Moreover, cytolysis among few parathyroid cells was also noted on day 30 following cadmium exposure (Fig. 15).

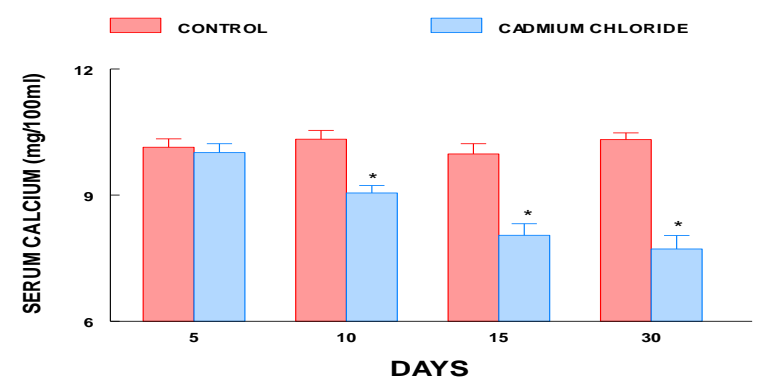

Figure 8. Serum calcium levels of long-term cadmium chloride treated Euphlyctis cyanophlyctis. Values are mean \pm S.E. of six specimens. Asterisk indicates significant differences $(\mathrm{P}<0.05)$ from control.

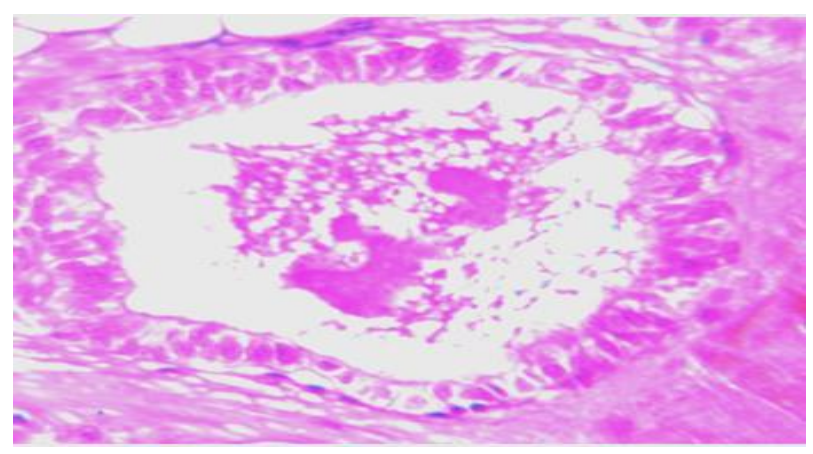

Figure 9. Ultimobranchial gland of 15 day cadmium chloride treated Euphlyctis cyanophlyctis exhibiting weak staining response in the cytoplasm. H\&E stain; mag. x 200

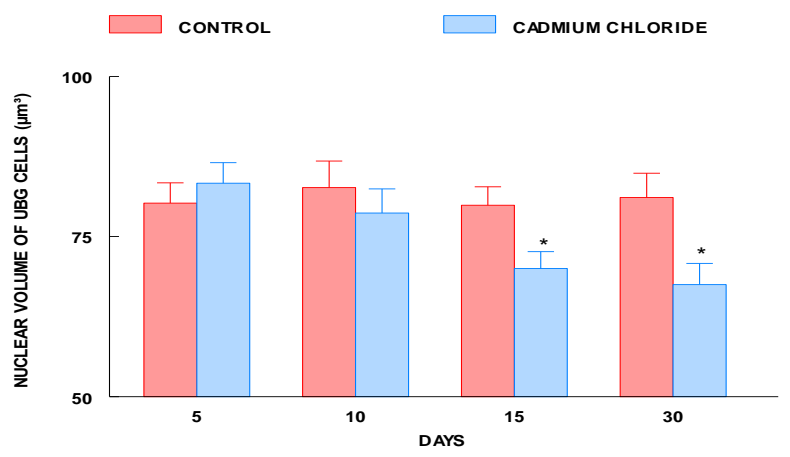

Figure 10. Nuclear volume of ultimobranchial cells of long-term cadmium chloride treated Euphlyctis cyanophlyctis. Values are mean \pm SE of six specimens. Asterisk indicates significant differences $(\mathrm{P}<0.05)$ from the control group.

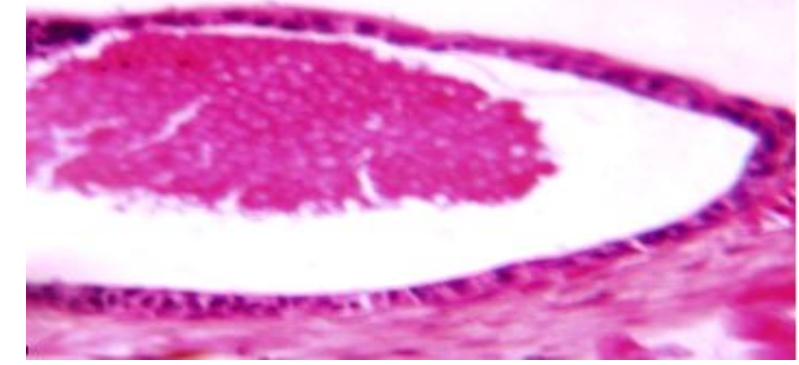

Figure 11. Ultimobranchial gland of 15 day cadmium chloride treated Euphlyctis cyanophlyctis exhibiting reduction of height of follicular epithelium. H\&E; mag x 50 .

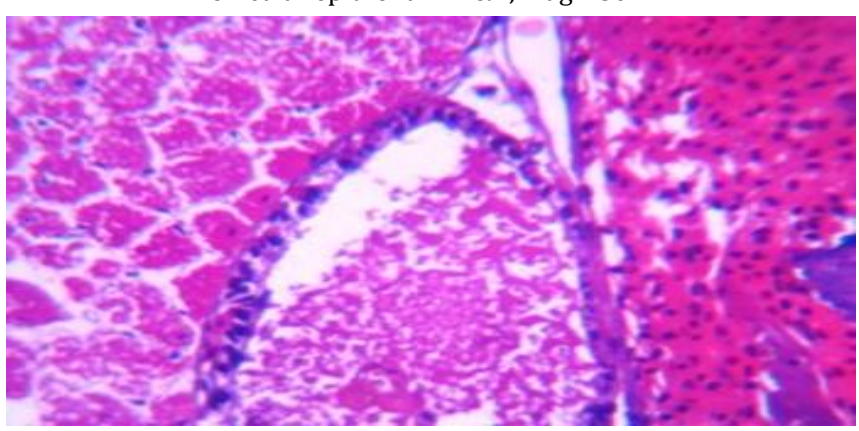

Figure 12. Ultimobranchial gland of 30 day cadmium chloride treated Euphlyctis cyanophlyctis exhibiting single layered follicular epithelium and degeneration. H\&E; mag x 50.

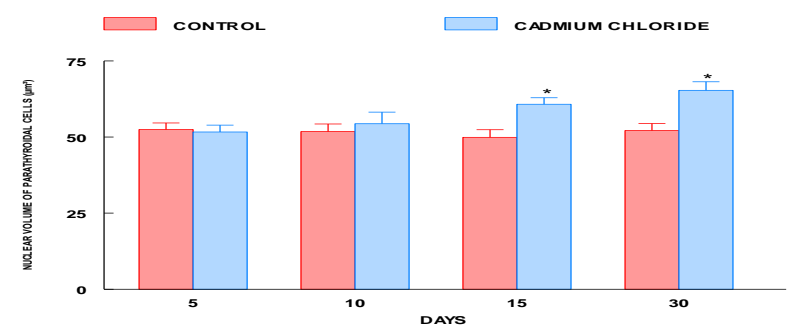

Figure 13. Nuclear volume of parathyroid cells of long-term cadmium chloride treated Euphlyctis cyanophlyctis. Values are mean $\pm \mathrm{SE}$ of six specimens. Asterisk indicates significant differences $(\mathrm{P}<$ 0.05) from the control group.

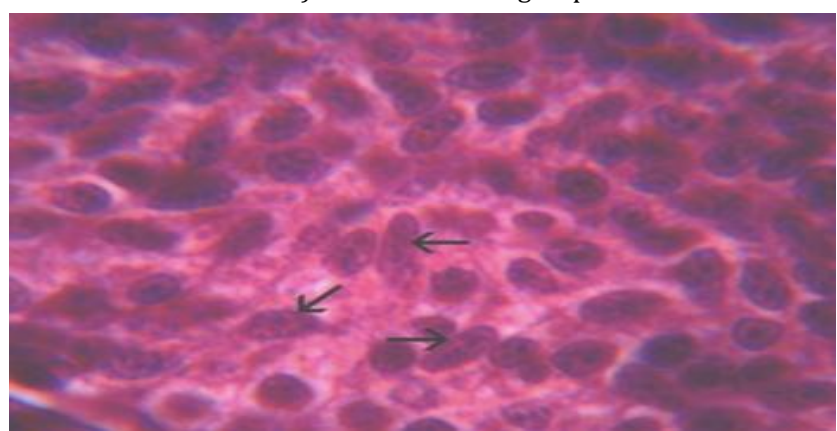

Figure 14. Parathyroid gland of 15 day cadmium chloride treated Euphlyctis cyanophlyctis exhibiting elongated (arrows) and hyperchromatic nuclei. H\&E stain; mag. x 500.

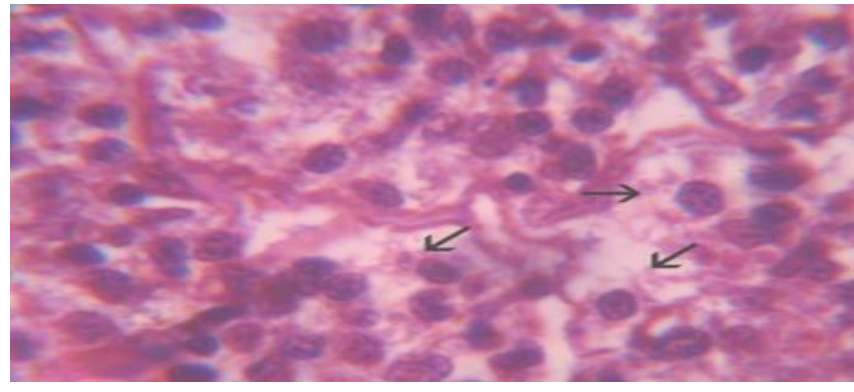

Figure 15. Parathyroid gland of 30 day cadmium chloride treated Euphlyctis cyanophlyctis exhibiting cytolysis (arrows). H\&E stain; mag. $x$ 500 


\section{DISCUSSION}

Cadmium exposed frogs exhibited inactivity of ultimobranchial glands, as evident by poor cytoplasmic staining response and shrunk nuclear volumes in ultimobranchial cells. Moreover, the follicular epithelia demonstrated reduced in height plus degeneration and vacuolization. No similar report is available regarding the cadmium toxicity in ultimobranchial glands of frogs; therefore, this is the first report. The inactivity of ultimobranchial glands could be attributed to the perpetual hypocalcemia provoked by cadmium toxicity. This is in conformity with similar observations reported previously by other investigators after exposure of fish to various toxicants including cadmium (13); deltamethrin (14); metacid (15); cypermethrin (16) and botanical pesticides (17). The findings of the present study are also supported by reports from earlier investigators who found inactivity of ultimobranchial glands in response to experimentally induced hypocalcemia by the administration of calcitonin to the fish (Anguilla anguilla (18); Gasterosteus aculeatus (19); Clarias batrachus (마); Heteropneus tesfossilis (21), amphibian: Bufoviridis (22), Ranatigrina $(\underline{23,24})$ and reptiles:

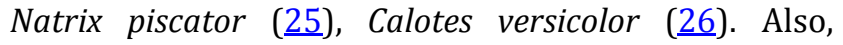
published observations of Anderson and Capen (27) support those of the present study, as they documented low ultimobranchial glands activity after inducing hypocalcemia in Iguana iguana by keeping them on a

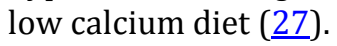

In contrast to the findings regarding inactivity of ultimobranchial glands in fish (13) following cadmium exposure, few investigators have reported hyperactivity of calcitonin secreting cells in mammals after cadmium toxicity $(\underline{28,29})$. Brzoska and Moniuszko-Jakoniuk have reported an increase in serum calcitonin levels in rats exposed to cadmium $(\underline{30})$. It is of interest that cadmium has the opposite effect on the activity of hypo-calcemic glands (ultimobranchial cells in non-mammals, and calcitonin cells in mammals). It is important to point out that in non-mammals, the ultimobranchial cells remain separately whereas in mammals they fuse with thyroid gland and remain as dispersed calcitonin secreting cells (31). Further studies are warranted to fully investigate the mechanisms of cadmium action in non-mammals and mammals regarding the synthesis and release of calcitonin. In the present study, cellular degeneration and vacuolization resulted in reduced height of the epithelia of ultimobranchial glands in cadmium exposed frogs. This may be attributed to the continuous disuse of the ultimobranchial gland caused by prolonged hypocalcemia induced in cadmium exposed frogs.

The hyperactivity of parathyroid gland cells was noted in cadmium treated frogs as evident by the increased volume of the elongated and hyper-chromatic nuclei. Parathyroid hormone has been reported to provoke hypercalcemia in vertebrates by controlling the electrolyte exchanges at three major sites: intestine, bones and kidneys (르). The present study derives support from the observations of Pilak Marcinkiewicz et al. (28) and Tripathi and Srivastav (29) who have also noticed hyperactivity of parathyroid cells in cadmium exposed rats. Moreover, in these rats Brzoska and Moniuszko Jakoniuk ( $\underline{30})$ have reported the elevated parathyroid hormone levels in the blood. Tripathi et al. (프) have reported hyperactive parathyroid cells in Chlorpyrifos treated rats. Bone demineralization has been reported after cadmium exposure to rats $(\underline{34})$ and carp fish $(\underline{35})$. Since we found no reports on the action of cadmium in frog parathyroid glands in the literature, it appears logical to compare our findings with those in other vertebrates where parathyroid is present. The bone demineralization has been interpreted as a mechanism to restore the plasma calcium levels. Consistently, the hyperactivity of parathyroid glands in the present study may be explained by the increased release of parathyroid hormone to reverse the hypocalcemia observed in cadmium treated Indian skipper frogs, $E$. cyanophlyctis.

\section{CONCLUSION}

Based on the findings, we can conclude that exposure to cadmium adversely affected the ultimobranchial and parathyroid glands in the treated frog. The disturbances in these vital endocrine glands may be one of the reasons for the decline in the population of this frog species in the aquatic environment contaminated with cadmium and other toxic heavy metals.

\section{ACKNOWLEDGEMENT}

The authors are thankful to the Head, Department of Zoology, DDU Gorakhpur University, Gorakhpur, India, for the cooperation and providing the necessary laboratory facilities for conducting this research.

\section{CONFLICT OF INTERESTS}

The authors declare no conflict of interests during the course of conducting this study.

\section{REFERENCES}

1. Hale EP, Jarchow JL. The status of the tarahumara frog (Rana tarahumara) in the United States and Mexico: part II. report to Arizona Game and Fish department and U.S. Fish and Wildlife Service. Albuquerque, NM, p. 102, 1988.

2. Clarkson RW, Rorabaugh JC. Status of leopard frogs (Rana pipiens Complex: ranidae) in Arizona and Southeastern California. The Southwestern Natularist.1989;34(4):531-538.

3. Sredl MJ. Ranid frog conservation and management. Nongame and endangered Wildlife Program Technical report 121. Nongame Branch, Wildlife Management Division, Arizona Game and Fish Department, Phoenix, AZ, pp. 89, 1997.

4. Calfee RD, Little EE. Toxicity of cadmium, copper, and zinc to the threatened Chiricahua leopard frog (Lithobates [Rana] chiricahuensis). Bulletin of Environmental Contamination and Toxicology. 2017;99(6):679-683.

5. Srivastav Ajai K, Srivastav S, Mishra D, et al. Cadmium attenuates blood calcium and phosphate in the Indian 
skipper frog, Euphlyctis cyanophlyctis. International Journal of Zoological Investigations. 2018A;4(2):149156.

6. Srivastav Ajai K, Srivastav S, Srivastav Sunil K, Suzuki N. Alterations in the serum electrolytes of the Indian skipper frog Euphlyctis cyanophlyctis caused by an organophosphate pesticide: Chlorpyrifos. Jordanian Journal of Biological Sciences. 2018 B;11(4):395-399.

7. Pigott GM, Tucker BW. Seafood: Effects of technology on nutrition. New York: Marcel Dekker, Inc., 1990.

8. Ruiter A. Contaminants in fish. In A. Ruiter (Ed.), Fish and fishery products composition, nutritive properties and stability (pp. 261-285). Guildford: Cab International, 1995.

9. Annabi A, Said K, Messaoudi I. Cadmium: Bioaccumulation, histopathology and detoxifying mechanisms in fish. American Journal of Research Communication. 2013;1(4):60-79.

10. Perera P, Kodithuwakku SP, Sundarabarathy TV, Edirisinghe U. Bioaccumulation of cadmium in freshwater fish: An environmental perspective. Insight Ecology. 2015;4 (1):1-12.

11. Borgmann U, Couillard Y, Doyle P, Dixon DG. Toxicity of sixty-three metals and metalloids to Hyalella azteca at two levels of water hardness. Environmental Toxicology and Chemistry. 2005;24(3):641-652.

12. Ahmadi Z, Ashrafizadeh M. Down regulation of osteocalcin gene in chickens treated with cadmium. Iranian Journal of Toxicology. 2019;13(1):1-4.

13. Rai R, Mishra D, Srivastav SK, Srivastav Ajai K. Ultimobranchial gland of a freshwater teleost, Heteropneustes fossilis in response to cadmium treatment. Environmental Toxicology. 2009;24(6):589593.

14. Srivastav AK, Srivastava SK, Mishra D, et al. Ultimobranchial gland of freshwater catfish, Heteropneustes fossilis in response to deltamethrin treatment. Bulletin of Environmental Contamination and Toxicology. 2002;68(4):584-591.

15. Mishra D, Srivastav SK, Srivastav AK. Plasma calcium and inorganic phosphate levels of a teleost Heteropneustes fossilis exposed to metacid-50. Malaysian Applied Biology. 2004;33(2):19-25.

16. Mishra D, Srivastav SK, Srivastav AK. Effects of the insecticide cypermethrin on plasma calcium and ultimobranchial gland of the teleost Heteropneustes fossilis. Ecotoxicology and Environmental Safety. 2005;60(2):193-197.

17. Prasad M, Kumar A, Srivastav SK, et al. Nerium indicum, a botanical pesticide affects ultimobranchial gland of a teleost, Heteropneustes fossilis. Environmental Toxicology. 2013;28(12):661-665.

18. Peignoux-Deville J, Lopez E, Lallier F, et al. Responses of ultimobranchial body in eels (Anguilla anguilla L.) maintained in seawater and experimentally matured to injections of synthetic salmon calcitonin. Cell Tissue Research. 1975;64 (1):73-83.

19. Wendelaar Bonga SE. Effect of synthetic salmon calcitonin and low ambient calcium on plasma calcium, ultimobranchial cells, Stannius bodies and prolactin cells in the teleost Gasterosteus aculeatus. General and Comparative Endocrinology. 1980;40(1):99-108.

20. Srivastav SP, Swarup K, Singh S, et al. Effect of calcitonin administration on ultimobranchial gland, Stannius corpuscles and prolactin cells in the male catfish, Clarias batrachus. Archives de Biologie Bruxelles.1989;100:385392.

21. Srivastav AK, Singh S, Mishra D, et al. Ultimobranchial gland of freshwater catfish Heteropneustes fossilis in response to calcitonin administration. Pesquisa Veterinária Brasileira. 2009;29(12):963-968.

22. Boschwitz D. The antagonistic effects of exogenous calcitonin and calcium on the ultimobranchial body of Bufoviridis (Amphibia Anura). Journal of Herpetology. 1973;7(3):195-200.

23. Srivastav AK, Rani L. Influence of calcitonin administration on serum calcium and inorganic phosphate of the frog, Rana tigrina. General and Comparative Endocrinology.1989A;74(1):14-17.

24. Srivastav AK, Rani L. Ultimobranchial body and parathyroid gland of the frog, Rana tigrina in response to calcitonin administration. Biological Structures and Morphogenesis.1989 B;2(4):136-140.

25. Srivastav Ajai K, Rani L. Ultimobranchial body and parathyroid gland of the freshwater snake, Natrix piscator in response to vitamin $\mathrm{D}_{3}$ administration. Journal of Experimental Zoology. 1992;262(3):255-262.

26. Srivastav AK, Srivastava B, Mishra D, et al. Calcitonin induced alterations in the ultimobranchial and parathyroid glands of garden lizard, Calotes versicolor. Turkish Journal of Zoology. 2011;35(1):9-14.

27. Anderson MP, Capen CC. Ultrastructural evolution of parathyroid and ultimobranchial glands in iguanas with experimental nutritional osteodystrophy. General and Comparative Endocrinology.1976;30(2):209-222.

28. Pilat-Marcinkiewicz B, Brzoska MM, Moniuszko-Jakoniuk J. Thyroid and parathyroid function and structure in male rats chronically exposed to cadmium. Polish Journal of Environmental Studies. 2008;17(1):113-120.

29. Tripathi S, Srivastav AK. Alterations in the serum electrolytes, calcitonin cells and parathyroid gland of Wistar rat in response to administration of cadmium. Proc. Intern. Con. Environ. Pollution and Remediation. Ottawa, Ontario, Canada, 17-19 August, Paper No. 12, 2011.

30. Brzoska M,Moniuszko-Jakoniuk J. Effect of low-level lifetime exposure to cadmium on calcitropic hormones in aged female rats. Archives of Toxicology. 2005;79 (11):636-646.

31. Srivastav AK, Rani L. Mammalian calcitonin cells: Retrospect and prospect. Biological Structure and Morphogenesis. 1988;1:117-123.

32. Srivastav AK, Das VK, Srivastav SK, Suzuki N. Amphibian calcium regulation: Physiological aspects. Zoologica Poloniae. 2000;45:7-26.

33. Tripathi S, Suzuki N, Srivastav AK. Response of serum minerals (calcium, phosphate and magnesium) and endocrine glands (calcitonin cells and parathyroid glands) of Wistar rat after chlorpyrifos administration. Microscopy Research and Technique. 2013;76(7):673678.

34. Pilat-Marcinkiewicz B, Sawicki B, Brzoska MM, Zabel M. Preliminary immunohistochemical study of $C$ cells of the thyroid and endocrine cells of the parathyroid glands in rats after prolonged exposure to cadmium. Folia Histochemica et Cytobiologica. 2001;39(2):191-192.

35. Koyama J, Itazawa Y. Effects of oral administration of cadmium on fish. I. Analytical results of the blood and bones. Nippon Suisan Gakkaishi. 1977;43:523-526. 